\title{
BREEDING AND AGRONOMIC PERFORMANCE OF NEW SMOOTH BROMEGRASS CULTIVAR KRUŠEVAČKI 46 (K-46)
}

\author{
Dejan Sokolović*1, Snežana Babić ${ }^{1}$, Jasmina Radović ${ }^{1}$, Zoran Lugić ${ }^{1}$, \\ Tomáš Vymyslickýn, Daniela Knotová ${ }^{2}$, Mirjana Petrović1
}

\begin{abstract}
Summary
Smooth bromegrass (Bromus inermis Leyss.) is rhizomatous perennial forage grass species spread all over Serbia, mostly beside the roads and at the edges of semi-xerophylous or xerophylous natural grasslands. Stabile and high forage yield, classify Smooth bromegrass in a group of forage grasses suitable for mixtures composing for drought conditions and poor soils in agro-ecological conditions of Serbia. It can be used traditionally for hay production, but also in quality mixtures with legumes for silage or haylage production. Cultivar K-46 is created by multiple phenotypic recurrent selection of populations collected across central Serbia. The main breeding goal was developing of genotypes of Bromus inermis with improved yield and chemical composition of dry matter. Since this grass species generally have been characterised with a lot of large but indelicate leaves, improvement of its biomass quality requires breeding of leaf parameters (size, number, position, etc.). In plot trial on three locations in two years period (2015 and 2016) cultivar K-46 reached average DMY of $6400 \mathrm{~kg} \mathrm{ha}^{-1}$. The average height of plants at the moment of cutting was $81.6 \mathrm{~cm}$. Crude protein content was $11.61 \mathrm{~g} \mathrm{~kg}^{-1}$ of dry matter in the first cut and $13.51 \mathrm{~g} \mathrm{~kg}^{-1}$ in the second cut, which represents the good quality of grass biomass. New cultivar $\mathrm{K}-46$, which is registered in December 2017, is suitable for mixtures composing for long-lasting and durable grasslands on light, marginal and dry soils. It stabilises land and produces enough amount of quality herbage which can be used with legumes species as complete forage meal for ruminants. It is adapted for cutting and tolerates dry, poor and eroded soils, therefore it shows best results on grasslands on hilly mountainous areas.
\end{abstract}

Key words: dry matter yield, forage quality, breeding, smooth bromegrass

\section{Introduction}

Production of high quality and affordable herbage is the main prerequisite of successful and sustainable animal production. A major part of herbage produced on farms consists of perennial grasses, which are a natural food for ruminants and cenobionts of different natural grasslands or main components of sown grasslands. There are many cool-season perennial kinds of grass which are important in animal feed production, but unfavourable climate, limited water availability and low soil fertility reduce the number of grass species which can produce enough quality forage. One of the grass species which can be grown in such production conditions is smooth bromegrass (Bromus inermis Leyss.).

The genus Bromus contains more than 100 species distributed all over the world and some of them are cultivated and widely grown for hay, pasture and land melioration. Smooth bromegrass is the most commonly cultivated perennial bromegrass species in North America (Vogel et al., 1996), Eastern Europe and large areas of temperate Asia (Casler et al. 2000), where it actually originates from. It was introduced in North America in 1884 but did not receive widespread acceptance until the drought years of the 1930s (Casler et al., 2000).

\footnotetext{
Original Scientific Paper (Originalni naučni rad)

${ }^{1}$ Sokolović D, Babić S, Radović J, Lugić Z, Petrović M, Institute for forage crops Kruševac, 37251 Globoder, Serbia

${ }^{2}$ Vymyslický T, Knotová D, Research Institute for Fodder Crops Ltd., Zahradni 1, 664 41, Troubsko, Czech Republic e-mail: dejan.sokolovic@ikbks.com
} 
This forage species is a relatively drought-tolerant, perennial (it can live even over 10 years) and rhizomatous. Cultivated smooth bromegrass is an auto-allo-octaploid $(2 \mathrm{n}=8 \mathrm{x}=56$ chromosomes) species, and mainly cross-pollinated (Fernandez et al., 2001). It is characterised with erect growth with steams high up to 120 $\mathrm{cm}$, carrying a lot of large but indelicate leaves. Inflorescence of smooth bromegrass is panicle and produce very large seeds in comparison with other perennial grasses. The seed show rapid loss of germination already in the $4^{\text {th }}$ year after harvest and that is a major problem in seed production of this species (Vogel et al., 1996).

It is widespread in Serbia (Sokolović et al., 2017), mostly at the edges of semi-xerophylous or xerophylous natural grasslands of alliance Festucion vallesiaceae and beside the roads next to mesophylous grasslands which sin-taxonomically belong to order Arrhenatheretalia.

As all perennial grasses, it grows well on fertile and moderately moist soils, but since it is drought resistant, best results are achieved on dry, light and permeable soils. It is susceptible to long flooding and marshland. As a fodder crop, it has been using mostly in mixtures with other grass species and legumes for hay production, but also for grazing or haylage and silage production. It achieves high and stabile herbage yield even on poor soil and that qualify it for establishing grasslands on hilly mountainous areas of Serbia.

Contemporary cultivars of smooth bromegrass are generally very productive and may rich green herbage yield $40-50 \mathrm{t} \mathrm{ha}^{-1}$ and over $13 \mathrm{t}$ ha $^{-1}$ of dry matter yield (Mihajlović et al., 2001). It belongs to a group of secondary grasses, with moderate herbage quality, although it can be increased by adequate earlier phases of cutting. Crude protein content in smooth bromegrass dry matter, depending on the phase of maturity, has been ranged from 12 to more than $20 \%$. If it is utilised at the beginning of the heading, crude protein content is ranged between 17 and $18 \%$ (Stjepanović et al., 2008), with very good DM digestibility from 60 to $70 \%$ (Carpenter and Casler, 1990; Vogel et al., 1996). This grass species has been characterised by excellent regeneration after cutting during years of full utilisation.
At breeding and improvement of cultivars of smooth bromegrass has been worked very long, from the beginning of 20th century, especially in the USA (Vogel et al., 1996, Casler et al., 2000), but progress has been very slow. Since the development of the first famous cultivar Lincoln in 1942 in USA, achieved average annual forage yield breeding gain was about 0.5 $\mathrm{t} \mathrm{ha}^{-1}$. But, after that time, there were no measurable increases in total forage yield in North America (Casler et al., 2000). Some practical results have been accomplished for increased in vitro dry matter digestibility (IVDMD), (Vogel et al., 2015), disease resistance and regrowth. Also, selection for increased forage yield was differently effective in various breeding methods used. Among and within-family selection reached $3.0 \%$ gain per cycle which was 2.1 times more effective than half-sib family selection (1.4\% gain) (Casler, 2008).

Slow overall improvement of smooth bromegrass genotypes can be partly attributed to relatively low resources and partly to breeding material originated essentially from wild or natural germplasm (Sokolovic et al., 2017) and short breeding processes - most cultivars represent one cycle of selection or less. Therefore, much of the variability present among smooth bromegrass cultivars and breeding populations arose from natural selection and adaptive responses in natural populations (Babić et al., 2010).

In Europe smooth bromegrass as a forage species and its breeding was quite neglected in the past since there are a lot of forage grass species with high production of herbage with good digestibility of dry matter. As a result, there are only a few cultivars registered in Europe. In recent time with global weather changing and drought increasing, smooth bromegrass importance as a forage species has been growing.

The main breeding goal in this work was the development of genotypes of Bromus inermis with improved yield and chemical composition of dry matter, by multiple phenotypic recurrent selection of populations collected across central Serbia. Since this grass species generally have been characterised with a lot of large but indelicate leaves, improvement of its biomass quality requires breeding of leaf parameters 
(size, number, position, etc.). There are some investigations on smooth bromegrass indicating that space plant phenotypic selection can be used to improve forage nutritive value, but not forage dry matter yield (Carpenter and Casler, 1990). The most important conclusion of their research is that dry matter yield remained unchanged when the nutritive value was increased by breeding, indicating that progress in DM quality breeding is possible without significantly yield decreasing. DM quality of smooth bromegrass can be improved with selection of cultivars with different maturity which can be used in a different phase in the mixtures, as it is achieved in other grass species (Babić et al., 2017).

\section{Material and methods}

Breeding process. Basic collection in this smooth bromegrass breeding process - consisted of 6 autochthonous populations collected in mountain localities of central Serbia (Table 1).

Basic collection investigated in space plants nursery $(60 \times 60 \mathrm{~cm})$ with 30 plants per population from 2006 to 2008 . Nine space plant traits were evaluated during three years and 18 best genotypes were selected based on these analyses. Selected genotypes were from localities Nerađe, Mitrovo Polje and Pleš. These 18 genotypes were intercrossed and sown in the nursery (seed of one plant per row of 30 individuals) and evaluated during two years trial (2009 and 2010). Additional phenotypic analyses (leaf width (LW) and number of leaves on the tiller (LN) and evaluation of yield (number of tillers - NT), plant height (PH), and dry matter yield per plant (DMY)) were performed. Twenty best plants with overall mark above four (scoring 1-5) were chosen and included in the polycross. After analyses of seed production five most productive were selected and included in the final polycross for new synthetic cultivar development.

The breeding method used was restricted phenotypic recurrent selection with clonal propagation of selected genotypes. Main breeding criteria were improved DMY and forage quality, but also drought tolerance and limiting agro-ecological conditions and an increased ratio of leaves in total forage. Ideotype was a cultivar of Bromus inermis for composing of grass legumes mixtures and utilisation as hay or haylage. The final goal of breeding was developing of genotypes with improved yield and chemical composition of dry matter.

Plot trials for cultivar registration. Investigation of productivity and forage quality of candidate cultivars was performed in the network of plot trials organised by the Commission for registration of cultivars in agricultural plant species of Ministry of agriculture, forestry and water management. The trial was conducted on three locations: Kruševac, Sombor and Sremska Mitrovica in three years, 2014-2016. It was established in a completely randomised block design in four replications with plots $10 \mathrm{~m}^{2}$ in size $(5 \times 2$ $\mathrm{m})$. Plots were manually sown in rows $20 \mathrm{~cm}$ apart, in March 2014 with sowing rate $30 \mathrm{~kg} \mathrm{ha}^{-1}$.

In both years of full utilisation (2015-2016) the trial was cut twice or three times depending on locality and year and green mass yield (GMY) was determined. Cutting of the first cut in both years was performed in the phase of the beginning of heading. Green forage samples were air dried on $65^{\circ} \mathrm{C}$ and dry matter yield

Table 1. Origin of populations included in the breeding process of smooth bromegrass cv. K-46 Tabela 1. Poreklo populacija uključenih u oplemenjivanje sorte bezosnog vlasena K-46

\begin{tabular}{cllcc}
\hline Pop. & Locality & \multicolumn{2}{c}{ GPS coordinates } & Altitude $(\mathrm{m})$ \\
\hline 1 & Nerađe, Kopaonik & N43 26.47 & E20 53.26 & 1004 \\
2 & Mitrovo Polje, Goč & N43 30.62 & E20 52.67 & 695 \\
3 & Rendara, Kopaonik & N43 20.10 & E20 51.38 & 1518 \\
4 & Čestobrodica, Južni Kučaj & N44 21.05 & E19 30.24 & 590 \\
5 & Pleš, Kopaonik & N43 29.09 & E20 54.35 & 623 \\
6 & Farma, Vlasina & N42 42.82 & E22 22.71 & 1303 \\
\hline
\end{tabular}


(DMY) was calculated. Plant high (PH) was measured before cutting. Plot density (PD), overwintering (OW) and lodging (L) were visually scored (1-9).

Dry matter quality was determined by standard laboratory methods in the second year of the trial on two cuts from locality Kruševac. Weende system of analysis was used for determining of ash content, crude protein content (CP), crude fibre content (CF) and ether extract (EE). NDF was detected by method Van Soest et al. (1991) and ADF was determined by solubilisation of cellulose with sulphuric acid. Protein yield (PY) was calculated for 2015 from DMY and $\mathrm{PC}$ and represent per unit area.

Results for GMY, DMY and PY, were analysed by ANOVA and LSD test. All meas- urements and evaluations were performed by standard methodology for the investigation of cultivars of forage crops in the process of registration and introduction in production.

\section{Results and discussion}

A basic collection of 6 autochthonous populations was investigated for three years. After detailed evaluation and analyses of nine traits 18 best genotypes originated from localities Nerađe, Mitrovo Polje and Pleš were selected. Selected genotypes were evaluated in the next breeding cycle during two years of plants full development. A lot of additional phenotypic traits and yield components were measured. On the basis of these analyses 20 best plants with overall mark above four (Table 2) were

Table 2. Characteristics of 20 chosen genotypes for polycross forming

Tabela 2. Karakteristike 20 izabranih genotipova uključenih u polikros

\begin{tabular}{|c|c|c|c|c|c|c|c|}
\hline Genotype & Origin & $\begin{array}{l}\text { Mark } \\
(1-5)\end{array}$ & $\mathrm{PH}(\mathrm{cm})$ & LW (mm) & $\mathrm{LN}$ & NT & DMY (g) \\
\hline 1 & \multirow{10}{*}{$\begin{array}{l}\frac{\pi}{\tilde{U}} \\
\text { Z }\end{array}$} & 5 & 103 & 16 & 5.5 & 73 & 418 \\
\hline 2 & & 5 & 125 & 16.5 & 6 & 67 & 409 \\
\hline 3 & & 5 & 126 & 17.5 & 5.5 & 57 & 422 \\
\hline 4 & & 5 & 125 & 21.5 & 6.5 & 76 & 535 \\
\hline 5 & & 5 & 132 & 18 & 7 & 90 & 686 \\
\hline 6 & & 5 & 118 & 17 & 6 & 149 & 983 \\
\hline 7 & & 4 & 122 & 18 & 6 & 77 & 543 \\
\hline 8 & & 3 & 105 & 17 & 4.5 & 50 & 385 \\
\hline 9 & & 3 & 96 & 23 & 4.5 & 36 & 366 \\
\hline 10 & & 3 & 100 & 20 & 5.5 & 38 & 378 \\
\hline Average & \multirow{8}{*}{ 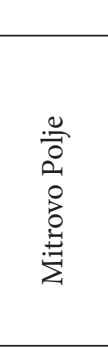 } & 4.3 & 115.2 & 18.4 & 6.25 & 71.3 & 512.5 \\
\hline 11 & & 4 & 112 & 22 & 8 & 43 & 459 \\
\hline 12 & & 3 & 123 & 20 & 7 & 52 & 405 \\
\hline 13 & & 5 & 117 & 20 & 5 & 56 & 486 \\
\hline 14 & & 4 & 108 & 19 & 6 & 59 & 502 \\
\hline 15 & & 5 & 137 & 19.5 & 7.5 & 58 & 566 \\
\hline 16 & & 5 & 127 & 18 & 5.5 & 75 & 619 \\
\hline 17 & & 4 & 104 & 17.5 & 5 & 94 & 856 \\
\hline Average & & 4.29 & 118.3 & 19.8 & 6.2 & 62.4 & 556.1 \\
\hline 18 & \multirow{3}{*}{$\frac{\sqrt{a}}{a}$} & 4 & 96 & 13 & 4,5 & 60 & 522 \\
\hline 19 & & 5 & 100 & 18 & 4 & 94 & 902 \\
\hline 20 & & 4 & 107 & 17 & 5.5 & 98 & 899 \\
\hline \multicolumn{2}{|l|}{ Average } & 4.33 & 101 & 16 & 4 & 84 & 774.3 \\
\hline \multicolumn{2}{|c|}{ Overall average } & 4.31 & 111.5 & 18.1 & 5.48 & 72.6 & 614.3 \\
\hline
\end{tabular}

PH - plant height; LW - leaf width; LN - number of leaves on the tiller; NT - number of tillers; DMY - dry matter yield per plant 
Table 3. Plants height and evaluation of cultivar in two years plot trial Tabela 3. Visina biljaka i ocene sklopa sorte u dve godine proučavanja

\begin{tabular}{lcccccc}
\hline Locality & Year & Cutting date & PH $(\mathrm{cm})$ & PD & L & OW \\
\hline \multirow{4}{*}{ Sombor } & 2015 & 28.05. & 58.0 & 9 & 9 & 9 \\
& 2016 & 19.05. & 63.0 & 9 & 9 & 9 \\
& Average & - & 60.5 & 9 & 9 & 9 \\
\hline \multirow{3}{*}{ Kruševac } & 2015 & 28.05. & 93.3 & 8 & 9 & 9 \\
& 2016 & 10.05. & 83.4 & 8 & 9 & 9 \\
& Average & - & 88.3 & 8 & 9 & 9 \\
\hline S. Mitrovica & 2015 & 26.05. & 96.0 & 9 & 9 & 9 \\
Year average & 2015 & - & 82.4 & 8.67 & 9 & 9 \\
& 2016 & - & 73.2 & 8.5 & 9 & 9 \\
\hline Trial average & $(2015-16)$ & - & 81.6 & 8.67 & 9 & 9 \\
\hline
\end{tabular}

PH - plant height; PD (1 low density - 9 full stand); L (1 100\% lodged - 9 without lodging); OW (1 without survived plants $-9100 \%$ survival)

chosen for further breeding steps. They were originated from three localities Nerađe (10 genotypes), Mitrovo Polje (seven genotypes) and Pleš (three genotypes). Average leaf width of these genotypes was $1.8 \mathrm{~cm}$ and number of leaves on each tiller almost 5.5 in average. There were genotypes which produce more than 900 $\mathrm{g}$ of DM per plant, but the overall average was lower $(614.3 \mathrm{~g})$. These 20 genotypes were clonally propagated and planted in polycross where they intercrossed with each other. After harvesting of genotypes from the polycross in 2012 average seed yield was calculated and five genotypes with highest seed production were chosen to form synthetic cultivar.

The created cultivar of smooth bromegrass (Bromus inermis Leyss.) was included in the trial network for registration in three locations as candidate cultivar. The stand of the new cultivar in the moment of cutting was in average $81.6 \mathrm{~cm}$ high, without lodging and with very good overwintering and ground cover (Table 3 ).

Plants were semi-erect, with improved number and size of leaves dark green in colour.

In the plot trials on three locations in two full production years, new cultivar reached to-

Table 4. Green matter yield and dry matter yield of the new cultivar in plot trial

Tabela 4. Prinos zelene mase i suve materije nove sorte u dvogodišnjem ogledu

\begin{tabular}{lccc}
\hline Locality & Year & GMY $\left(\mathrm{t} \mathrm{ha}^{-1}\right)$ & DMY $\left(\mathrm{t} \mathrm{ha}^{-1}\right)$ \\
\hline \multirow{3}{*}{ Sombor } & 2015 & 13.59 & 4.42 \\
& 2016 & 19.00 & 3.54 \\
\cline { 2 - 4 } & Average & 16.29 & 3.98 \\
\hline \multirow{2}{*}{ Kruševac } & 2015 & 26.00 & 7.50 \\
& 2016 & 31.85 & 8.76 \\
\hline Sremska Mitrovica & Average & 28.93 & 8.13 \\
\hline \multirow{2}{*}{ Year average } & 2015 & 14.95 & 7.79 \\
\hline Trial average & 2015 & 18.18 & 6.57 \\
\hline
\end{tabular}

GMY - green mass yield; DMY - dry matter yield 
Table 5. DM chemical composition and protein yield of K-46 in the first and second cut

Tabela 5. Hemijski sastav suve materije i prinos proteina sorte K-46 u prvom i drugom otkosu

\begin{tabular}{cccccccc}
\hline Cut & $\begin{array}{c}\text { Ash } \\
\left(\mathrm{g} \mathrm{kg}^{-1}\right)\end{array}$ & $\begin{array}{c}\mathrm{CP} \\
\left(\mathrm{g} \mathrm{kg}^{-1}\right)\end{array}$ & $\begin{array}{c}\mathrm{CF} \\
\left(\mathrm{g} \mathrm{kg}^{-1}\right)\end{array}$ & $\begin{array}{c}\mathrm{EE} \\
\left(\mathrm{g} \mathrm{kg}^{-1}\right)\end{array}$ & $\begin{array}{c}\mathrm{NDF} \\
\left(\mathrm{g} \mathrm{kg}^{-1}\right)\end{array}$ & $\begin{array}{c}\mathrm{ADF} \\
\left(\mathrm{g} \mathrm{kg}^{-1}\right)\end{array}$ & $\begin{array}{c}\text { PY } \\
\left(\mathrm{k} \mathrm{gha}^{-1}\right)\end{array}$ \\
\hline I & 7.69 & 11.61 & 33.23 & 3.09 & 60.19 & 40.33 & 607.1 \\
$\mathrm{II}$ & 11.51 & 13.51 & 30.57 & 5.39 & 57.26 & 36.34 & 306.8 \\
\hline \multicolumn{7}{l}{ Total annual PY in 2015 } \\
\hline
\end{tabular}

$C P$ - crude protein; $C F$ - crude fibre; EE - ether extract; NDF - neutral detergent fibre; ADF - acid detergent fibre; $P Y$ - protein yield

tal average GMY of $21 \mathrm{t} \mathrm{ha}^{-1}$, or $6.4 \mathrm{t} \mathrm{ha}^{-1}$ of DM (Table 4). The highest yield of the new cultivar in the first year of yield evaluation was achieved in locality Sremska Mitrovica, almost $7.8 \mathrm{t} \mathrm{ha}^{-1}$. The best average results new Bromus inermis cultivar K-46 showed on locality Globoder, Kruševac where it is bred (more than $8.1 \mathrm{t} \mathrm{ha}^{-1}$ ). The similar yield of smooth bromegrass populations and cultivars was reported in different multi-location and multiyear trials in USA, and ranged from 7 to $9 \mathrm{t} \mathrm{ha}^{-1}$ (Casler and Brummer, 2005; Casler, 2008) or even up to $11 \mathrm{t} \mathrm{ha}^{-1}$ (Carpenter and Casler, 1990; Casler et al., 2001).

Crude protein content in dry matter of the first cut was $11.6 \mathrm{~g} \mathrm{~kg}^{-1}$, while in second it was more than $13.5 \mathrm{~g} \mathrm{~kg}^{-1}$, which characterises good quality biomass. Accordingly, new cultivar K-46 produced more than $900 \mathrm{~kg} \mathrm{ha}^{-1}$ of pure crude protein in the year 2015 .

\section{Conclusions}

New registered smooth bromegrass cultivar K-46 was characterised with high production of quality dry matter. It is very suitable for mixtures composing for durable and persistent grasslands on light, droughty and marginal soils for hay, haylage or silage production. It can stabilise and renovate the land and produce with legumes large amounts of good quality animal feed with for sustainable animal husbandry.

\section{Acknowledgement}

This research has been funded by the Ministry of education, science and technological development of the Republic of Serbia through Project TR 31057.

\section{References}

Babić S, Sokolović D, Radović J, Anđelković B, Živković B (2010): Varijabilnost najvažnijih osobina autohtonih populacija lisičjeg repa (Alopecurus pratensis L.) i bezosnog vlasena (Bromus inermis Leyss.). Zbornik radova XV savetovanja o biotehnologiji, 15. (16), 26-27. mart, Čačak, 129-134.

Babić S, Sokolović D, Radović J, Lugić Z, Anđelković S, Vasić T, Petrović M (2017): Oplemenjivanje sorti ježevice različitog vremena stasavanja. Selekcija i semenarstvo, 23(1): 1-9.

Carpenter JA, Casler MD (1990): Divergent phenotypic selection response in smooth bromegrass for forage yield and nutritive value. Crop Sci. 30: 17-22.

Casler MD (2008): Among-and-within-Family Selectionin Eight Forage Grass Populations. Crop Sci. 48: 434-442.

Casler MD, Brummer EC (2005): Forage yield of smooth bromegrass collections from rural cemeteries. Crop Sci. 45: 2510-2516.

Casler MD, Vogel KP, Balasko JA, Berdahl JD, Miller DA, Hansen JL, Fritz JO (2000): Genetic progress from 50 years of smooth bromegrass breeding. Crop Sci. 40:13-22.

Casler MD, Vogel KP, Balasko JA, Berdahl JD, Miller DA, Hansen JL, Fritz JO (2001): Latitudinal and longitudinal adaptation of smooth bromegrass populations. Crop Sci. 41: 1456-1460.

Fernandez YSN, Somers DJ, Coulman BE (2001): Estimatingthe genetic relationship of hybrid bromegrass to smooth bromegrassand meadow bromegrass using RAPD markers. Plant Breeding, 120: 149-153. 
Mihajlović I, Mladenović G, Vučković S (2001): Proizvodne karakteristike trava u agroekološkim uslovima istočne Srbije. Arhiv za poljoprivredne nauke, 62: 267-274.

Sokolović D, Babić S, Radović J, Lugić Z, Simić A, Zornić V, Petrović M (2017): Genetic resources of perennial forage grasses in Serbia: Current state, broadening and evaluation. Selekcija i semenarstvo, 23(1): 69-82.

Stjepanović M, Štafa Z, Bukvić G (2008): Trave za proizvodnju krme i sjemena, Zagreb.

Van Soest PJ, Robertson JB, Lewis BA (1991): Methods for dietary fibre, neutral detergent fibre and non-starch polysaccharides in relation to animal nutrition. J. Dairy Sci., 74: 3583-3597.

Vogel KP, Mitchell RB, Waldron BL, Haferkamp MR, Berdahl JD, Baltensperger DD, Erickson G, Klopfenstein TJ (2015): Registration of 'Newell' smooth bromegrass. Journal of Plant Registrations 9: 35-40.

Vogel KP, Moore KJ, Moser LE (1996): Bromegrasses. p. 535-567. In Moser L.E. et al. (ed.) Cool-season forage grasses. Agron. Monogr. 34. ASA, CSSA, and SSSA, Madison, WI. 


\title{
AGRONOMSKE KARAKTERISTIKE NOVE SORTE BEZOSNOG VLASENA KRUŠEVAČKI 46 (K-46)
}

\author{
Dejan Sokolović, Snežana Babić, Jasmina Radović, Zoran Lugić, \\ Tomáš Vymyslický, Daniela Knotová, Mirjana Petrović
}

\begin{abstract}
Sažetak
Bezosni vlasen (Bromus inermisLeyss.) je višegodišnja krmna rizomatska trava koja je rasprostranjena skoro u celoj Srbiji ali se nalazi uglavnom pored puteva i na rubovima semikserofilnih i kserofilnih prirodnih travnjaka. Karakteriše ga visok i stabilan prinos krme, što ga svrstava u grupu bitnih krmnih trava za komponovanje smeša naročito pri uslovima suše i na lošim zemljištima u agroekološkim uslovima Srbije. Kao krmna biljka se koristi uglavnom u smešama sa drugim travama i leguminozama za proizvodnju sena ali se može koristiti i za spravljanje silaže.

Sorta K46 je dobijena višestrukom rekurentnom selekcijom genotipova koji su kolekcionisani širom centralne Srbije. Glavni oplemenjivački cilj pri oplemenjivanju ove sorte bezosnog vlasena je bio poboljšanje prinosa i hemijskog sastava suve materije. Inače ova biljna vrsta se odlikuje visokom olistalošću - velikim ali u isto vreme dosta grubim listovima, pa se poboljšanje kvaliteta suve materije postiže i pravovremenim iskorišćavanjem biljne mase u fazi pred početak klasanja i oplemenjivanjem karakteristika lista. Sorta je kosidbenog tipa i podnosi sušna, slaba i erodirana zemljišta, pa stoga odlične rezultate pokazuje na travnjacima u brdsko-planinskom području, iako se može sejati i u niziji.

U sortnim ogledima na tri lokacije u dvogodišnjem periodu (2015 i 2016), dostigla je prosečan prinos suve materije od oko $6400 \mathrm{kgha}^{-1}$. Prosečna visina biljaka u trenutku kosidbe je iznosila $81,6 \mathrm{~cm}$. Sadržaj sirovih proteina u prvom otkosu je iznosio $11,61 \mathrm{gkg}^{-1}$ a u drugom otkosu 13,51 $\mathrm{gkg}^{-1}$ suve materije, što predstavlja dobar kvalitet travne biomase.

Nova sorta bezosnog vlasena je registrovana u decembru 2017. i veoma je pogodna za komponovanje smeša za dugotrajne i otporne travnjake na lakim, marginalnim i sušnim zemljištima gde stabilizuje zemljište i produkuje dovoljnu količinu stočne hrane zadovoljavajućeg kvaliteta koji se uz upotrebu leguminoza u smešama može bitno popraviti.
\end{abstract}

Ključne reči: prinos suve materije, kvalitet krme, oplemenjivanje, bezosni vlasen

Primljen: 15.03.2019.

Prihvaćen: 23.04.2019. 